\title{
Apontamentos Sobre Linguagem e Hermenêutica em Agostinho
}

\author{
Notes on Language and Hermeneutics in Augustine
}

\author{
Victor Hugo de Oliveira Marques \\ (Universidade Católica Dom Bosco, Afeganistão) \\ Julielton de Melo Targino \\ (Instituto João Paulo II, Brasil)
}

\section{Resumo}

A linguagem e a hermenêutica são duas grandes áreas da Filosofia e estão presentes na discussão filosófica de Agostinho. Esta pesquisa buscou apontar as relações destas temáticas no pensamento do autor com base em algumas obras primordiais para atingir este objetivo. Sendo assim, foram identificados os conceitos bases que constituem a linguagem (sinais, significado, palavra) e a hermenêutica (sinais figurados, sentido literal, obscuridades) em seus apontamentos. A primeira, é uma estrutura que possibilita a comunicação, por meio da convenção de vocábulos fazendo acontecer a mediação entre 0 pensamento e a palavra, seja ela falada ou escrita. A segunda, por sua vez, ao reconhecer que o problema das obscuridades é de natureza linguística, faz com que se interprete corretamente os textos sagrados. A linguagem é como que pré-formada na razão; e a teoria da interpretação de Agostinho se constrói através da linguagem. Assim, ambas, constituem uma via objetiva que faz a mediação para acessar a verdade (Deus).

Palavra-chave: Linguagem. Agostinho. Hermenêutica. Semiótica.

\begin{abstract}
The language and hermeneutics are two major areas of the Philosophy, and they are present in St. Augustine's philosophical discussion. This research aimed to point out there relations of these themes in the author's thought, based on some primordial works to achieve this goal. Thus, the basic concepts that constitute language (signs, meaning, word) and hermeneutics (figurative signs, literal meaning, obscurities) were identified in their notes. The first is a structure that enables communication, through the convention of words, making the mediation between thought and word, whether spoken or written, happen. The second, in turn, by recognizing that the problem of obscurity has linguistic nature, it makes the sacred texts correctly interpreted. Language is as though preformed in reason; and St. Augustine's theory of interpretation is constructed through language. Thus, both constitute an objective way that mediates to access the truth (God).
\end{abstract}

Keywords: Language. Hermeneutics. Augustine. Semiotics. 


\section{Introdução}

A linguagem e a hermenêutica são dois temas fundamentais na discussão filosófica, de modo especial na Filosofia Contemporânea. Contudo, é sempre importante lembrar que os contemporâneos, parafraseando Newton, estão, como que anões, em ombros de gigantes. Neste sentido, este artigo busca investigar, no pensamento de Agostinho, a conexão entre estas duas temáticas e as suas consequências para a discussão filosófica agostiniana.

O autor identifica que o início da linguagem se dá por meio dos sentidos, que desperta na razão a necessidade de uma linguagem para a comunicação. Ele reconhece que a linguagem possui um papel fundamental na comunicação, servindo tanto como mediação do pensamento ao conhecimento, quanto para a resolução das obscuridades no exercício interpretativo. Com esta última, Agostinho se distancia de seus predecessores alegóricos e refunda a Hermenêutica no campo da linguagem. Assim, ele esclarece alguns termos indispensáveis e propõe regras para se chegar a uma interpretação precisa.

Conclui-se, através desta investigação, que a linguagem e a hermenêutica, no pensamento de Agostinho, e em toda filosofia agostiniana, constituem uma "via objetiva" para a verdade, isto é, uma mediação inevitável para a experiência com Deus.

\section{Aproximações Semióticas no Pensamento Agostiniano}

O tema da linguagem, não menos que outros, possui uma ampla discussão no pensamento do Bispo de 
Hipona, influenciando a muitos ao longo da história ${ }^{1}$. Nos chamados: "primeiros escritos" (Contra os Acadêmicos, A Ordem, A grandeza da Alma, e O Mestre), podem ser notados as primeiras discussões do autor acerca do tema da linguagem. Mais detidamente, a uma espécie de "semiótica", cuja ideia de sinal e de signo aparecem em relevo.

$\mathrm{Na}$ obra "A Ordem", Agostinho inicia sua investigação da linguagem ligada ao problema do "ensinar", ou seja, ela está vinculada ao problema da comunicação. Para tanto, o autor recupera uma reflexão a respeito dos sentidos, em especial da visão e da audição², por meio dos quais a comunicação é possível. Agostinho descreve que:

[...] são três os gêneros de coisas em que aparece o razoável: um está no que se faz em relação a um fim, o segundo está no que se diz e o terceiro no prazer. O primeiro nos admoesta a não fazer nada temerariamente; o segundo adverte-nos a ensinar corretamente; o terceiro chama-nos à feliz contemplação. (2008, p. 234) (grifo nosso).

O autor explica, a partir do fragmento acima, que o sentido da visão está ligado à recepção do movimento dado e, portanto, a todo ato que visa um fim, ou seja, a visão está ligada não só ao conhecer teórico, mas ao conhecimento prático, ao qual segue a moral. O segundo

1 Como exemplo, Santo Agostinho é lembrado por Wittgenstein na questão da linguagem. (N. do A.)

2 Esta relação também aparece na obra Livre Arbítrio. "Consequentemente, esta verdade possui menos analogia com os objetos dos sentidos do tato, do gosto e do olfato do que com os objetos atingidos pelos sentidos do ouvido e da vista". (AGOSTINHO, 1995a, p. 122).

Ágora Filosófica, Recife, v. 21, n. 1, p. 145-169, jan./abr., 2021 • 147 
está ligado ao sentido da audição que trata daquilo que se diz, a fala. E por fim, o terceiro que se refere ao prazer, convidando a admirar a beleza. Assim, tendo presente a audição, que está ligada com a palavra dita, a qual ocorre a comunicação (o ensino) é que a discussão da linguagem se torna fundamental.

A fim de sistematizar a comunicação, Agostinho explica

[...] a razão percebeu que se deviam impor vocábulos às coisas, expressando alguns sons para que, uma vez que os homens não podiam penetrar mutuamente em suas almas, usassem do sentido como intermediário para associar-se entre si. (2008, p. 235).

Neste trecho, o autor revela a necessidade de mediação para que a comunicação ocorra. Essa mediação se dá por meio da convenção de "vocábulos". A linguagem, portanto, é entendida, como uma estrutura oriunda do pensamento formada por vocábulos, tal como comenta: “A linguagem está no pensamento interior como que préformada, antes que seja exteriorizada oralmente ou por escrito". (HORN, 2006, p. 16). As letras ou vocábulos servem para "tornar concreto" tanto o pensamento quanto as palavras pronunciadas nos diálogos, além de proporcionar aos ausentes, o que eles perderam. Nos termos de Daur, Migne e Weigel, "A linguagem é um instrumento prático através do qual estamos em grau de ensinar e de dar informações, de evocar à memória fatos ou conceitos e recordá-los aos outros". (2009, p. 27).

Posteriormente aos primeiros escritos, num texto catequético do já, então Bispo de Hipona, denominado "Doutrina Cristã", Agostinho aprofunda seu pensamento sobre os vocábulos. Estes podem ter sentido próprio ou 
podem assinalar outras coisas. Nos termos do autor:

Ao escrever o livro anterior sobre as coisas (De rebus) procurei prevenir que se fizesse atenção aí, apenas ao que as coisas são em si próprias, prescindindo do que possam significar além de seu sentido próprio. Agora, ao tratar sobre sinais (De signis), advirto que não se dê atenção ao que as coisas são em si, mas unicamente ao que significam, isto é, que elas se manifestam sinais de algo diferente. (2002a, p. 85) (grifo nosso).

O vocábulo que tem seu sentido nas próprias coisas, ou seja, que diz daquilo que se refere (a coisa em si mesma) imediatamente, Agostinho diz que esse tem um "sentido próprio". Porém, nem todo vocábulo se refere ao sentido próprio, pode ocorrer que um sinal se refira a outra coisa. De modo geral, Agostinho sustenta que todo vocábulo é um "sinal", ou seja, "[...] toda coisa que, além da impressão que produz em nossos sentidos, faz com que nos venha ao pensamento outra ideia distinta". (2002a, p. 85). Como exemplo, Agostinho se lembra do vocábulo "pegada", pois, além do seu sentido em si mesmo, ela remete a outra coisa, qual seja, o animal que ela representa.

Isso significa que "sinal" não é uma coisa à qual nossa percepção deve se ater por primeiro - o seu valor não está no que aparece -, mas naquilo que esse sinal representa ou significa, ou seja, aquilo do qual ele depende. Grosso modo, o sinal é uma mediação de algo; é a ferramenta utilizada para representar ou indicar uma coisa.

O caráter mediador do sinal configura a ideia de significado - "aquilo que é percebido através do sinal, ou seja, aquilo que a alma consegue apreender das coisas 
pelo sinal" (AGOSTINHO, 2008, p. 385) - podendo ser conhecido ou permanecer oculto. Este, por sua vez, pode ser uma ideia, imagem etc. Segundo Horn (2006, p. 8), o significado é compreendido em Agostinho "como a indicação de uma coisa ou de um conteúdo". Entre os sinais, Agostinho identifica dois tipos. Os sinais naturais "são os que, sem intenção nem desejo de significação, dão a conhecer, por si próprios, alguma outra coisa além do que são em si". (2002a, p. 86). Como exemplo, "a fumaça é sinal de fogo". (IBIDEM, p. 85). Estes sinais naturais têm conotação imediata, enquanto os sinais convencionais "são os que todos os seres vivos mutuamente se trocam para manifestar os movimentos de sua alma, tais sejam as sensações e os pensamentos". (IBIDEM, p. 86). Ambos são utilizados na comunicação, seja na fala ou na escrita.

Por meio da descrição dos sinais, Agostinho articula as coisas ao pensamento, uma vez que a discussão da linguagem, aqui, está muito longe de ser um fim em si mesmo - como ocorre dentro da linguistic turn - tendo ainda o caráter gnosiológico. O pensamento, com efeito, materializa-se, sendo exteriorizado através da palavra dita ou escrita, que por sua vez, é representada por "signos". Cary destaca que, no caso das palavras, Agostinho "was in fact the first thinker to classify words as a species of signs". (2011, p. 194)3. Sendo assim, a palavra - que é formada por signos -, pode representar outras palavras/sinais (por exemplo, a palavra "nome" - que é uma palavra/sinal representa outra palavra/sinal como "João" que é um nome), além das coisas que não são sinais (por exemplo a palavra "água" que é uma palavra/sinal que representa

\footnotetext{
${ }^{3 \prime \prime}$ foi, de fato, o primeiro pensador a classificar as palavras como uma espécie de sinais" (tradução nossa).

150 • Ágora Filosófica, Recife, v. 21, n. 1, p. 145-169, jan./abr., 2021
} 
uma coisa da realidade). Assim, "as coisas designadas e o seu conhecimento possuem uma primazia diante das palavras como meros sinais para elas. As palavras estão meramente a serviço do conteúdo indicado através delas". (HORN, 2006, p. 11); elas são ferramentas para a compreensão da realidade. Por fim, Horn finaliza a investigação sobre a função da palavra em Santo Agostinho afirmando que "Palavras são, com efeito, sinais, mas elas não possuem nenhuma força constitutiva de conhecimento. Antes, sua função consiste unicamente em 'lembrar' ou 'admoestar'”. (2006, p. 12).

Aquele que capta estas palavras (signos), deve buscar compreender o significado (sinais) que está no interior ${ }^{4}$.

A palavra interior constitui, portanto, de certo modo, o núcleo central da filosofia agostiniana da linguagem, como elemento mediador entre a coisa e o signo e entre aquele que fala e aquele que ouve; a palavra exterior, todavia, não equivale a simples estímulo ou a mera sugestão, mas mais à capacidade de transmitir a verdade que habita ininteriorehomine. (PIERETTI apud FITZGERALD, 2018, p. 611) (grifo no original).

A ideia de "palavra interior" é o ponto de referência

\begin{abstract}
4"Sobre as muitas coisas que entendemos consultamos não aquelas cujas palavras soam no exterior, mas a verdade que interiormente preside à própria mente, movidos talvez pelas palavras para que consultemos. E quem é consultado ensina, o qual é Cristo que, como se diz, habita no homem interior, isto é, a virtude incomutável de Deus e a eterna Sabedoria" (AGOSTINHO, 2008, pp. 406-407).

5 Agostinho recusa a teoria da reminiscência platônica e elabora a teoria da iluminação divina: "Ora, se fossem apenas recordações de conhecimentos anteriores, nem todos, nem mesmo uma maioria que fosse, poderia se lembrar ao serem interrogados sobre esse Ágora Filosófica, Recife, v. 21, n. 1, p. 145-169, jan./abr., 2021 • 151
\end{abstract}


que o sujeito utiliza para se relacionar com as coisas e para se comunicar. Exemplo: ao se deparar com uma coisa, o sujeito diz seu nome (lápis). Este sinal pronunciado (voz) acessa a mente de quem escuta (palavra interior) que fornece o seu significado (objeto fino, utilizado para escrever ou desenhar). A palavra interior além de formular o significado e fazer a mediação entre a coisa e o seu sinal, serve como o ponto de referência da verdade. Assim, a mediação feita é certificada antes de ser transmitida, possuindo uma eficácia.

Sinal, significado e Palavra Interior formam um conjunto fundamental da linguagem e funcionam articuladamente, é o que explica Pieretti:

A vox articulata é o veículo que serve para suscitar no pensamento (in cogitatione) algo diferente, isto é, o significado; este último, por sua vez, não é, simplesmente o referente exterior do signo, mas o que dele é percebido mentalmente por aquele que o recebe. Porque a linguagem é um instrumento de comunicação, a vox articulata e o significatus são unidos por uma ligação que não é natural, mas de origem convencional. (PIERETTI, apud FITZGERALD, 2018, p. 610) (grifo no original).

determinado assunto. Pois nem todos devem ter sido geômetras na vida anterior, visto que esses são tão poucos entre os homens que dificilmente se encontra alguém. Assim, é preferível acreditar que a natureza da alma intelectiva foi criada de tal modo que, aplicada ao inteligível segundo sua natureza, e tendo assim disposto o Criador, possa ver esses conhecimentos em certa luz incorpórea de sua própria natureza" (AGOSTINHO, 1995b, p.390). Neste sentido, o Mestre e a Palavra Interior possuem o mesmo significado. Esta teoria garante a existência das concepções do conhecimento na memória, ou seja, todas as questões identificadas são verdadeiras porque foram de antemão, iluminadas pela luz divina. 
A "palavra dita" (vox articulada ou vocábulo) constitui-se, para Agostinho, o meio natural do pensamento utilizado para expressá-lo na fala. Ela suscita no pensamento daquele que ouve o significado - como referente exterior do sinal - e a imagem mental.

Em certo sentido, a estrutura semiótica em Agostinho é vista - segundo alguns autores - como uma articulação "diádica" ( $\delta \cup a \delta ı k a)$ ou até mesmo "triádica" ( apenas a relação entre o sinal e seu significado - uma vez que "sinal" já pressupõe a relação entre coisarepresentação e no "significado", a relação palavra interior-conhecimento. De outro lado, o sinal pode ser considerado como resultado de uma conexão do nome (vocábulo), do pensamento e da coisa (AGOSTINHO, 2008, p. 235). Esta estrutura triádica ${ }^{6}$ do sinal linguístico pode ser identificada como "uma situação semiótica". (PIERETTI apud FITZGERALD, 2018, p. 610). Para esclarecer ainda mais este vínculo, Pieretti afirma que:

[...] a res, que corresponde àquilo a que o signo se refere e que pode ser percebido seja física, seja intelectualmente; o verbum, que equivale ao signo enquanto está para algo que não ele mesmo - isto é, a coisa - e que pode ser percebido pelo ouvinte quando é proferido; o dicibile, que corresponde ao conteúdo intelectual presente na mente daquele que fala, antes mesmo que o entregue às palavras; o dictio, que se identifica com o ato mesmo de falar. O que é transmitido, então, no processo da comunicação é o dicibile, que equivale ao significado concebido por aquele que dá o signo e que é expressado na dictio. (apud FITZGERALD, 2018, p.

\footnotetext{
${ }^{6}$ Esta relação tríade também aparece nas obras Doutrina Cristã. (AGOSTINHO, 2002a, p.85) e Princípios de Dialética (AGOSTINHO, 2003, p.72).
}

Ágora Filosófica, Recife, v. 21, n. 1, p. 145-169, jan./abr., $2021 \cdot 153$ 
Cary deixa claro esta perspectiva, no que tange a semiótica.

Greek semiotics had been exclusively a theory of inference, never a theory of linguistic meaning. This is why Platone vertreated words as a type of sign. Aristotle, likewise, is often thought to classify words as a type of sign in the opening page of his logical treatise On Interpretation, but this is in fact a medieval reading which assimilates Aristotle's view to Augustine's. [...] This is not a promising basis for a semiotic account of the nature of language. What enables Augustine to arrive at a semiotics of language is the distinctively Latinus age of terms like significare, which had no equivalent in Greek, because they concerned not the direction of inference from sign to thing signified, but the direction of expression from the soul's communicative intent to the bodily signs that express it. We can see this usage of significare quite vividly in Cicero's writing son rhetoric, in which significationes are bodily hints and gestures that convey the emotions of the speaker's soul (motus animi). It's Augustine who applies this expressionist semiotics to language, classifying words as signs used by the soul to signify and express its will to communicate. Augustine's semiotic theory of language is presented at the beginning of the second book of On Christian Doctrine, and becomes decisive for Western semiotic sever since. There could be no Saussure or Derrida without it. (2011, p. 195). ${ }^{7}$

\footnotetext{
7"A semiótica grega tinha sido exclusivamente uma teoria da inferência, nunca uma teoria do significado linguístico. É por isso que Platão nunca tratou as palavras como um tipo de sinal. Aristóteles, da mesma forma, é muitas vezes utilizado para classificar as palavras como um tipo de sinal na página de abertura de seu tratado lógico sobre interpretação, mas esta é de fato uma leitura medieval que assimila a visão de Aristóteles a de Agostinho. Esta não é uma base 154 • Ágora Filosófica, Recife, v. 21, n. 1, p. 145-169, jan./abr., 2021
} 
Em síntese, o autor comenta: "Fica, portanto, estabelecido que nada se ensina sem sinais e que o próprio conhecimento nos é mais precioso que os sinais pelos quais conhecemos". (AGOSTINHO, 2008, p. 400). Em outras palavras, mesmo que a finalidade seja explicitamente gnosiológica, esta depende, ao menos, de uma semiótica mínima; o que não diminui a importância da linguagem.

\section{Hermenêutica}

O que está se considerando aqui por hermenêutica, ou teoria da interpretação de Agostinho, é a capacidade de compreender e interpretar um texto corretamente (PESCH, 2015, p. 53). Esta ação é mais bem conhecida no trabalho agostiniano como "exegese" bíblica. Além do mais, Lopéz ressalta que "De todos modos, el hecho de haberse dedicado fundamentalmente a la interpretación de la Biblia no impide que su hermenêutica sea válida para la

promissora para um relato semiótico da natureza da linguagem. 0 que permite Agostinho chegar a uma semiótica da língua é o uso distintamente latino de termos como significare, que não tinha equivalente em grego, porque eles não se preocupavam com a direção de inferência de sinal para coisa significada, mas a direção de expressão da intenção comunicativa da alma aos sinais corporais que a expressam. Podemos ver esse uso de significare muito vividamente nos escritos de Cícero sobre retórica, em que significações são dicas corporais e gestos que transmitem as emoções da alma do falante (motus animi). É Agostinho quem aplica essa semiótica expressionista à linguagem, classificando as palavras como sinais usados pela alma para significar e expressar sua vontade de se comunicar. A teoria semiótica da linguagem de Agostinho é apresentada no início do segundo livro de Sobre a Doutrina Cristã, e torna-se decisiva para a semiótica ocidental desde então. Não poderia haver Saussure ou Derrida sem ele" (tradução livre).

Ágora Filosófica, Recife, v. 21, n. 1, p. 145-169, jan./abr., $2021 \cdot 155$ 
interpretación de otros textos". ${ }^{8}$ (2017, p. 70), bem como outras ciências que aplicam a interpretação para obterem êxito em suas pesquisas (IBIDEM, 2015, p. 54). Contudo, a discussão hermenêutica no Bispo de Hipona não está descolada de uma profunda análise da linguagem, o que, mais uma vez, nos leva a uma semiótica.

O autor desenvolveu sua teoria interpretativa de maneira mais precisa na obra "Doutrina Cristã" a qual pode ser considerada como uma das primeiras discussões acerca deste tema e serve como base para os estudos posteriores". A finalidade da obra consiste em "descobrir o que é para ser entendido e a maneira de expor com propriedade o que foi entendido". (AGOSTINHO, 2002a, p. 41). Neste trecho, o autor apresenta o objetivo do seu trabalho, aspecto importante para entender seu pensamento no campo hermenêutico, qual seja, a interpretação é dependente da linguagem.

Ele deixa manifesto seu desejo de apontar as normas ou regras que devem ser utilizadas para entender os livros santos. Sob esta perspectiva, o autor parte da influência judaica que já fazia exegese sobre os textos sagrados, mas com o olhar voltado ao problema da linguagem, que, segundo ele, era a verdadeira causa das obscuridades. Consequentemente, ao se compreender estes empecilhos, pode-se ensinar aos demais os métodos de uma sadia interpretação.

As obscuridades nas Sagradas Escrituras, dentro da tradição judaico-cristã da hermenêutica, eram explicadas

\footnotetext{
${ }^{84}$ De todos os modos, o fato de ter-se dedicado fundamentalmente a interpretação da Bíblia não impede que sua hermenêutica seja válida para a interpretação de outros textos" (tradução nossa).

${ }^{9}$ Como exemplo, Santo Agostinho é lembrado por Hegel, Heidegger e Gadamer na discussão hermenêutica. (N. do A.).

156 • Ágora Filosófica, Recife, v. 21, n. 1, p. 145-169, jan./abr., 2021
} 
como vontade de Deus - como ocorre em Filon de Alexandria e Orígenes de Alexandria. Deus, em sua sabedoria, criava as obscuridades para que nem todos pudessem conhecer sua verdade. Deus é que era a causa das obscuridades, e a hermenêutica consistia em ir ao encontro com Deus para que Ele revelasse o segredo por detrás das obscuridades. Em Agostinho, a verdade está em questão diante do tema da obscuridade. Para ele, ao contrário de seus antecessores, as obscuridades são problemas linguísticos, devendo, portanto, ser interpretadas pelos hermeneutas ${ }^{10}$. Isto se dá por conta das limitações humanas diante do tema do conhecimento, ou seja, o problema não está em Deus. Nesse sentido, Agostinho leva a discussão hermenêutica para o campo da linguagem, ou seja, torna-a acessível a qualquer um que, de posse desse conhecimento, queira fazer bom uso da interpretação.

Para vencer este desafio, o autor traça um itinerário de interpretação que visa superar as diversas realidades que dificultam o processo do conhecimento. Todavia, a sua teoria hermenêutica é construída através da análise das escrituras. Sendo importante ressaltar que o propósito hermenêutico do autor possui um caráter

10"Orígenes pensava que a interpretação alegórica, fundada, é verdade, numa rigorosa atenção ao texto, fornecia um acesso às doutrinas secretas que preenchem as lacunas da Regra de fé, proclamada abertamente pela Igreja. Agostinho excluía o esoterismo, insistindo no fato de que a doutrina devia ser determinada a partir do claro sentido literal das Escrituras, acessíveis a cada um". A afirmativa de Orígenes "de que a verdade das Escrituras residia em seu sentido espiritual" difere da de Santo Agostinho que acredita "que cada passagem deve ser literalmente verdadeira, mesmo se parece absurda ou em contradições com outras" (TRIGG apud FITZGERALD, 2018, p.732).

Ágora Filosófica, Recife, v. 21, n. 1, p. 145-169, jan./abr., $2021 \cdot 157$ 
apologético, como ele mesmo enuncia.

O homem temente a Deus procura diligentemente a vontade divina nas santas Escrituras. Pacificado pela piedade, que não ame as controvérsias. Munido do conhecimento das línguas, que não se veja embaraçado por palavras e expressões desconhecidas. Provido de certos conhecimentos necessários, que saiba identificar a natureza e as propriedades das coisas quando empregadas a título de comparação. Finalmente, apoiado na exatidão do texto obtido por trabalho consciencioso de correção, que ele, assim preparado, possa dissipar e resolver as ambiguidades das Escrituras. (AGOSTINHO, 2002a, p. 151) (grifo nosso).

Tendo em vista estes dados do temor, da piedade e da defesa que o hermeneuta precisa possuir, ele deve também ser impulsionado por uma reta intenção (AGOSTINHO, 2002a, p. 61). Alguns conhecimentos prévios são necessários para fazer certas distinções quanto ao conteúdo e aos atributos das coisas a serem comparadas. Assim, nota-se que o exercício hermenêutico precisa de um intérprete e de algo a ser interpretado. Nesta relação, Agostinho ressalta que o primeiro - o hermeneuta - tenha uma certa familiaridade com o segundo - neste caso, o texto - com o seu idioma no original ou as traduções disponíveis, para identificar as palavras ou expressões ambíguas. Fazendo esta observação, o itinerário será mais seguro.

Com esta compreensão, o hermeneuta alcançará o terceiro grau que é de suma importância no desenvolvimento desta pesquisa.

Depois desses dois graus do temor de Deus e da piedade, chega-se ao terceiro, o grau da ciência, 
justamente sobre o qual eu me propus escrever nesta obra. Porque é nesse grau que se há de exercitar todo estudioso das divinas Escrituras, com a intenção de não encontrar nelas outra coisa mais do que o dever de amar a Deus por Deus, e ao próximo por amor de Deus. (AGOSTINHO, 2002a, p.92-93) (grifo nosso).

É neste nível que corresponde à ciência, que vai se desenvolver toda a teoria agostiniana sobre a hermenêutica e seus métodos de interpretação para solucionar a insuficiência das palavras e seu valor relativo no aprendizado. Pollmann comenta esta atitude do autor que "opõe-se a uma abordagem anti-intelectual, ou carismática, para interpretação da Bíblia e escolhe um método científico que possa ser racionalmente seguido" (apud FITZGERALD, 2018, p. 488). Prossegue-se as pontuações do autor ainda no início de sua obra, que para solucionar esta problemática interpretativa se faz jus, analisar algumas regras que podem servir para aquele que se coloca no caminho de desvelamento das confusões de um texto.

A respeito da interpretação das Escrituras existem certas normas que me parecem poder ser ensinadas com proveito aos que se dedicam a este estudo. Assim poderão eles progredir não apenas lendo as obras de outros que esclareceram as obscuridades dos Livros santos, mas ainda progredir, com os esclarecimentos que eles próprios poderão dar a outros. (AGOSTINHO, 2002a, p. 31) (grifo nosso).

Agostinho identifica regras para interpretar e ressalta a capacidade que o intérprete possui para compreender as obscuridades e consequentemente para transmitir o que foi apreendido. Constrói-se assim, uma

Ágora Filosófica, Recife, v. 21, n. 1, p. 145-169, jan./abr., $2021 \cdot 159$ 
conexão entre aquilo que deve ser compreendido - o sentido literal do texto, e a reta intenção do hermeneuta que visa chegar a verdade expressa no pensamento daquele que o elaborou. Grondin, salienta ainda que

Esta conexão empresta à hermenêutica agostiniana um traço 'existencial' inconfundível, que se reencontra em todos os seus escritos [...]. O querer entender as escrituras não é nenhum processo indiferente, meramente epistêmico, que se passa entre um sujeito e um objeto, ele atesta a básica inquietação e maneira de ser de um ente que aspira por sentido. (1999, p. 72-73).

Este comentário levanta um ponto importante do movimento que Agostinho faz referente a busca de um sentido existencial, ou seja, mais do que discutir hermenêutica, o autor está fazendo um processo pessoal de investigação onde, ele obtém resultados e os transmite. E como foi dito anteriormente, o Mestre que é representado pela palavra interior, é um dado considerado como imediato no pensamento agostiniano. Em contrapartida, a linguagem é vista como um dado exterior e que possibilita a mediação. Assim, somente em Gadamer é possível identificar com clareza, na hermenêutica filosófica, que o texto e o sujeito estão em uma conexão hermenêutica ${ }^{11}$.

Para auxiliar na compreensão das relações entre a linguagem e a ação hermenêutica, Minghetti comenta que

[...] a linguagem da revelação no campo da teologia não se limita apenas a um enunciado, muito mais, ante sua tradução explora informações sobre um

11 Conferir na conhecida obra "Verdade e Método" - Hans-Georg Gadamer (N. do A.). 
determinado domínio que segundo a filosofia analítica seria a linguagem em seu locus natural, onde deva ser estudada e analisada. O caminho desta linguagem não vai da palavra ao significado, mas parte de um significado aceito e instituído, para analisar a palavra e seu contexto. (2016, p. 57).

Ao discutir os aspectos hermenêuticos agostinianos, nota-se os traços teológicos inseparáveis de sua filosofia. Esta interação do verbo divino com a humanidade se destaca como o ponto de partida de Agostinho. E para ele, toda esta análise feita pela hermenêutica fornece a validade de seus prejuízos. Grondin aponta ainda esta característica própria do autor, como influência nas postulações da linguagem na tradição, reconhecendo o destaque que ele atribui a hermenêutica.

[...] o pensamento agostiniano do verbum já teria feito jus, na tradição, ao ser da linguagem. $\mathrm{Na}$ compreensão da palavra como incarnação processual de um espírito, que, no entanto, está plenamente presente na palavra e contudo aponta para algo diverso, delineia-se a universalidade da ação hermenêutica sobre a linguagem. (grifo no original). (1999, p. 71).

Diante desta problemática, segundo Agostinho, o hermeneuta deve se apropriar-se do Mestre interior, que é Deus, para utilizar-se da razão, bem como do seu empenho no conhecimento do contexto, das línguas, das traduções etc. Ao fazer uma leitura integral, obter-se-á maior contato com o texto e consequentemente maior compreensão. Neste estudo, o autor identifica o sentido literal das escrituras, ou seja, a passagem que fala e possui o sentido em si mesma.

Em contrapartida, identifica-se os sinais figurados.

Ágora Filosófica, Recife, v. 21, n. 1, p. 145-169, jan./abr., 2021 • 161 
Eles "são figurados ou metafóricos, quando as mesmas coisas, que denominamos com seu termo próprio, são também tomadas para significar algo diferente". (AGOSTINHO, 2002a, p. 99). A questão levantada pelo autor indica a relação que possui entre um signo e seu significado caracterizando-se mutuamente, podendo ocasionar que a coisa significada é em contrapartida sinal de outra coisa. Ainda sobre esses sinais, Agostinho reforça que "quando alguns termos desconhecidos obrigam o leitor a vacilar, eles devem ser verificados, ou pelo estudo das línguas ou pelo conhecimento da natureza das coisas". (IBIDEM, 2002a, p. 109).

O conhecimento das línguas ${ }^{12}$ serve como um respaldo para que não haja incompreensões "Para combater a ignorância dos signos próprios, o grande remédio é o conhecimento das línguas". (IBIDEM, 2002a, p. 100). As traduções, salienta o autor, têm "[...] sido mais ajuda do que obstáculo à compreensão do texto, isso ao se tratar de leitores não negligentes". (IBIDEM, 2002a, p. 101). Elas auxiliam através de suas variedades a confrontar os textos e identificar o sentido que melhor se assemelha ao trecho em questão. Porém, pode acontecer de o tradutor, ao não compreender alguma ambiguidade do escrito original, enganar-se, o que ocasionará um outro sentido daquele que fora proposto pelo autor do texto. (AGOSTINHO, 2002a, p. 103).

Torna-se evidente que a Sagrada Escritura é um conjunto de sinais, compilada por vários autores que receberam de Deus a divina inspiração. Com esta

12 A língua $(y \lambda \omega ́ \sigma \sigma \alpha)$ é uma forma de linguagem utilizada por um conjunto de pessoas, de um país, de uma determinada cultura. Especificadamente nas Sagradas Escrituras, identifica-se o aramaico, o hebraico e o grego (N. do A.).

162 • Ágora Filosófica, Recife, v. 21, n. 1, p. 145-169, jan./abr., 2021 
consciência, é imprescindível fazer as devidas distinções em que as palavras são utilizadas diante do sentido que o texto visa outorgar.

[...] cujo propósito é única e somente apontar para a realidade além de si mesmos. As palavras, contudo, nunca podem representar as coisas significadas em sua completude, há uma descontinuidade entre o significado de um signo/proposição e a realidade a que o signo/proposição refere. (POLLMANN, 1996, apud FITZGERALD, 2018, p. 488).

Esta descontinuidade dos signos e da realidade que é enunciada nos Textos Sagrados torna-se íntegra, segundo Agostinho porque a limitação da linguagem material reveste-se de Deus ${ }^{13}$ que é absoluto, eterno e imutável $^{14}$. É Deus quem dá o primeiro passo em direção ao homem e é Ele que faz com que o homem compreenda (2002b, p. 445). Esta distância que se faz notar na filosofia agostiniana é encerrada em Cristo, o verdadeiro Mestre, ou seja, o divino e eterno que age fora do tempo, auxilia o homem para que alcance a verdade plena. Assim, para Agostinho a comunicação entre Deus e o homem só se torna possível por meio do verbo encarnado:

Antes de experimentar, julgavas poder falar de

\footnotetext{
${ }^{13} \mathrm{~A}$ verdade para o autor, objeto da sua busca existencial, é Deus a vida feliz é alegria nascida da verdade; pois é alegria nascida de ti, que és a verdade, ó Deus, minha luz, a salvação de minha face, meu Deus (AGOSTINHO, 2002b, p. 292). A verdade, equipara-se também "a fonte dos padrões de julgamento de que nossas mentes dependem" (HARRISON, apud FITZGERALD, 2018, p.954) (N. do A.).

14“Uma verdade é sempre uma proposição necessária e, por isso, imutável". (GILSON, 2006, p. 39). 
Deus; começas a perceber, e verificas ser impossível traduzir o que experimentas [...]. Disse e fomos feitos; mas nós não podemos dizer o que ele é. Seu Verbo, no qual ele nos criou, é seu Filho para que nós, em nossa fraqueza, de algum modo o exprimíssemos, ele se fez fraco. Podemos pôr o júbilo no lugar da palavra; trocar o verbo por uma palavra, não podemos. (1997, p. 1172).

A vontade divina faz com que haja este diálogo. $\mathrm{E}$ para o autor, é através da hermenêutica que o homem interpreta e compreende sem que o texto perca a sua originalidade, pois "A verdade fundamenta-se de modo permanente na razão das coisas e foi estabelecida por Deus". (AGOSTINHO, 2002a, p. 135).

Por fim, Deus sendo transcendente quis revelar-se aos homens que, dotados de razão, possuem a capacidade de corresponder a este desejo divino. Através dos sentidos compreenderam a necessidade de criar vocábulos. Neste âmbito, Deus comunica-se através das Escrituras, as quais foram escritas por mãos humanas que sendo limitadas, geram o problema das obscuridades. Este problema de compreensão é solucionado por Santo Agostinho com sua teoria da interpretação.

\section{Considerações Finais}

A partir da análise feita, algumas percepções são importantes. Tanto o pensador Agostinho (dos primeiros escritos) quanto o Bispo Agostinho (dos escritos posteriores) não rechaçam a ideia de uma linguagem: seja para a gnosiologia, seja para a hermenêutica. Embora a linguagem não tenha o peso que os contemporâneos dão, sua análise, no pensamento agostiniano não é menos importante. É com esse filósofo que as intuições de 
Aristóteles sobre o signo reaparecem, porém, agora, dentro de uma teoria do conhecimento. Agostinho não abandona sua noção de subjetividade ao tentar objetivar a discussão semiótica. Nesse sentido, ela vai se consolidar como uma via objetiva mediadora para a relação entre a subjetividade e a verdade.

É também dentro dessa mesma base, dessa "via objetiva" que a Hermenêutica vai aparecer em seu pensamento. Nem mesmo a ideia de subjetividade conservada pela lluminação Divina faz com que o Bispo de Hipona desista da linguagem, em função das exegeses alegóricas, como mediação elementar para 0 ato interpretativo. Agostinho assevera duras críticas aos alegoristas que transpõem para o nível teológico aquilo que é do nível humano, isto é, alegam a divindade das obscuridades - conferindo aos hermeneutas um lugar de destaque e um aval para especulações sem fundamentos - ao invés de enfrentar o verdadeiro problema das Escrituras: a construção significativa textual. Dentro da perspectiva hermenêutica, a semiótica é de fundamental importância, já que é pela ausência de um aprofundamento das estruturas da linguagem que se instala a ignorância e se dá vazão aos aproveitadores.

Interpretar, para Agostinho, é muito mais do que resolver problemas pontuais no texto ou mesmo evitar meros escândalos. É um ato de adentrar no universo da linguagem a qual o texto se expressa e somente mediante uma análise é possível reconhecer a totalidade da compreensão. A compreensão de que um texto é necessariamente certa construção de signos e que estes estão ligados a uma realidade histórico-cultural, torna a interpretação um ato de compromisso com a verdade (dimensão gnosiológica) e, ao mesmo tempo, com Deus

Ágora Filosófica, Recife, v. 21, n. 1, p. 145-169, jan./abr., 2021 • 165 
(dimensão teológica). Mas o que torna a Hermenêutica distinta de uma mera análise semiótica? É por meio do ato significativo do sinal que Agostinho abre espaço para o campo Hermenêutico. À medida que um sinal, além de se referir à coisa originária, pode quer dizer outra coisa, essa possibilidade significativa indica que há numa necessidade hermenêutica de distinção de sentidos. Quando um sentido deve ser prescindido por outro? Esta deve representar uma pergunta que abre o campo hermenêutico. A elasticidade significativa de um sinal que ao ser expresso imprime na mente de quem ouve um sentido distinto é a razão que deixa à mostra as obscuridades de um texto.

Assim, não é sem nenhum propósito que o filósofo inicia seu texto da Doutrina Cristã retomando seus conceitos semióticos. Compreender como se comportam os signos na linguagem é condição para uma boa exegese, mesmo sabendo que tais textos são produtores da Graça Divina no crente. Por meio desse estudo, a literalidade do texto, bem como sua figuração, toma um novo sentido na exegese, não levando, necessariamente ao processo alegorizante presentes no pensamento de Filon ou Orígenes. E por meio da consciência da alegoria que é a análise da linguagem se torna ainda mais necessária. Juntamente com essa compreensão semiótica, Agostinho adverte a aspectos como o uso das línguas clássicas, os contextos históricos cujos textos foram produzidos, entre outras regras, o que confere à linguagem mesma uma função de "moldura" na hora da interpretação. Deduz-se, assim, quanto a hermenêutica que, Agostinho constrói sua teoria resolvendo o problema das obscuridades através de um itinerário hermenêutico que deve ser percorrido. Este tem o seu início diante da revelação divina nas Sagradas 
Escrituras, despertando no intérprete o interesse de estudar o texto, se munindo dos atributos necessários para alcançar a autenticidade.

Linguagem e Hermenêutica, portanto, estão em sintonia no pensamento agostiniano. A linguagem tem por fim o conhecimento e a hermenêutica a perfeita experiência de Deus. Como verdade e Deus se coincidem em Agostinho, linguagem e hermenêutica buscam o mesmo fim. Mas não é somente por teleologia que ambas se cruzam, muito mais do seu fim último, linguagem e hermenêutica estão sob uma mesma base: a semiótica. Esta, aqui, deve ser lida como aquela análise necessária para a própria produção filosófica enquanto produção significativa do pensamento. Seria anacrônico dizer de uma Filosofia da Linguagem em Agostinho do mesmo modo como existe uma Filosofia da Linguagem na Filosofia Analítica do século XX. Por outro lado, não se pode negar que, o pensamento agostiniano não concebe à linguagem um lugar fundante no que diz respeito à produção da filosofia enquanto expressão do pensamento. É claro que, uma vez que se conhece o final da história, é fácil dizer que este já está no início; e não é intenção nossa de, desde uma virada linguística, querer dizer que ela já estava prevista em Agostinho. Contudo, o exercício da linguagem e da hermenêutica em Agostinho não deixa dúvidas de sua novidade, sobretudo no que tange na hermenêutica, quando esta passa ser fundada e co-habitar o terreno da linguagem. A imanência linguística que Agostinho dá à tarefa hermenêutica impede que a linguagem seja somente um subproduto epistemológico. Neste caso, se a linguagem dá a Hermenêutica uma novidade fundamental, em Agostinho, esta dá à linguagem a importância realmente necessária para que a discussão 
da linguagem não seja de um valor extra temporal.

\section{Referências}

AGOSTINHO. A Doutrina Cristã. São Paulo: Paulus, 2002a. AGOSTINHO. A Trindade. São Paulo: Paulus, 1995.

AGOSTINHO. Comentário aos salmos: Salmos 51-100. São Paulo: Paulus, 1997.

AGOSTINHO. Confissões.15. ed. São Paulo: Paulus, 2002b. AGOSTINHO. Contra os Acadêmicos, A Ordem, A Grandeza da Alma, O Mestre. São Paulo: Paulus, 2008. AGOSTINHO. O Livre-arbítrio. 2. ed. São Paulo: Paulus, 1995.

AGOSTINHO. Princípios de dialética. Bogotá: EdicionesUniandes, 2003.

CARY, P. The innerword prior tolanguage: Augustine as platonistalternativetogadamerianhermeneutics.

St.

David's, PA: PhilosophyToday, pp.192-198, 2011.

DAUR, K.D.; MIGNE, J. P.; WEIGEL, G. (Orgs.). De Magistro. Rio de Janeiro: Editora Vozes, 2009.

FITZGERALD, A. (Org.). Agostinho através dos tempos. São Paulo: Paulus, 2018.

GILSON, E. Introdução ao estudo de Santo Agostinho. São Paulo: Paulus, 2006.

GRONDIN, J. Introdução à hermenêutica filosófica. São Leopoldo: Unisinos, 1999.

HORN, C. Agostinho - Teoria linguística dos sinais. Porto Alegre: Veritas, v.51, n.1, p.5-17, Mar.2006.

LÓPEZ, I. Hermenéutica en la antigüedad tardía: Agustín de Hipona. Argentina: Cuadernos Medievales, n.22, pp.67-83, jun. 2017.

MINGHETTI, A. A. Por uma hermenêutica autoimplicada na tradução de AvreliiAvgvstiniem De magistro. Porto: CivitasAugustiniana, n.5, pp. 50-106, 2016. 
PESCH, E. H. Aspectos hermenêuticos em Santo Agostinho. Curitiba: Teologia e Espiritualidade, n.5, pp.5165, 2015.

Victor Hugo de Oliveira Marques

Doutor pelo Programa de Pós-Graduação em Desenvolvimento Local. Coordenador do Curso de Filosofia da UCDB. Docente do Curso de Filosofia da UCDB.

E-mail: vicgo@bol.com.br

Julielton de Melo Targino

Possui graduação em Filosofia pela Universidade Católica Dom Bosco. E-mail: julielton.targino@hotmail.com

Submetido: 19/03/2021 Aprovado: 15/04/2021 